\title{
Lessons learned in developing a green environment at the Engineering Faculty, University of Indonesia
}

\author{
Gabriel Andari Kristanto ${ }^{1, *}$, Cindy Priadi $^{1}$, Nyoman Suwartha ${ }^{1}$, Erly Bahsan ${ }^{1}$, and Arief Udhiarto ${ }^{2}$ \\ ${ }^{1}$ Civil Engineering Department Faculty of Engineering Universitas Indonesia, 16424 Depok, Indonesia \\ ${ }^{2}$ Electrical Engineering Faculty of Engineering Universitas Indonesia, 16424 Depok, Indonesia
}

\begin{abstract}
Today, institutions of higher education play increasingly active roles in helping achieve a sustainable society. This study aims to demonstrate the lessons learned in the development of a green environment at the Faculty of Engineering, University of Indonesia. This paper reviews the development of the necessary supporting infrastructure and discusses opportunities and challenges in establishing a green environment. The availability and condition of groundwater sources are identified, and the process by which canteen wastewater is treated by phytoremediation is described. Additionally, composting and recycling of solid wastes are encouraged in communities, and a model for an energy-efficient classroom is discussed. Three lessons learned are discussed: a focus on defining the program, continuous education and monitoring, and sources of funding. The implications of this study for relevant practices are also identified.
\end{abstract}

\section{Introduction}

Worldwide economic growth has caused the amount and volume of waste generated and energy consumed to increase exponentially. As a result, developing a sustainable society is a major challenge for many countries as they strive to balance green issues with economic development [1]. Increasing demands for energy and clean water coupled with a limited amount of resources mean that every human activity has a resulting impact on the environment. The term "sustainable development" was first defined in the Brundtland Report in 1987 as development that satisfies the needs of the present without diminishing the abilities and choices of future generations [2]. Although a general environmental awareness is more prominent among developed countries, many universities from emerging countries with visionary academic leaders are expanding their roles to solve global and environmental challenges [3, 4]. In Indonesia, several universities are starting to play increasingly active roles in helping the country achieve sustainability, as reflected in the increasing number of participating universities in Indonesia in the Green Metric World University Ranking (from 22 in 2010 to 25 in 2011). This ranking system was developed by the University of Indonesia (hereinafter called UI) in 2010; it applies specifically to sustainable and green campuses according to applicable conditions. The evaluations are based on qualitative and quantitative approaches and employ the Berlin Principles [5].

In line with the Research Agenda for Higher Education in Indonesia and Millennium Development Goals (MDG), the Faculty of Engineering at the
University of Indonesia (hereinafter, FTUI) developed a research theme for the period 2010-2014 entitled "Integrated Design in Urban Eco-technology for Quality of Life and Humanity". Consistent with this theme, FTUI aims to become a role model for building a community with a strong orientation toward a green and sustainable environment. Hence, an integrated program was launched on the FTUI campus with the theme of "FTUI Toward a Green and Sustainable Society." The program has several sub-programs consisting of solid waste, water and wastewater management, and energy savings. Research on waste management focuses on solid waste management to encourage the "3Rs"reduce, reuse, and recycle - and research on water management focuses on protecting a sustainable water supply in the neighborhood by the FTUI campus. Through this program, a classroom was developed as a model for energy efficiency. Subsequently, all research and results have been promoted throughout the FTUI community to increase awareness and encourage participation in developing a green and sustainable society.

\section{Framework}

The University of Indonesia (UI) with 14 faculties and numerous research centers and laboratories, is located in the city of Depok, West Java, Indonesia. Detailed descriptions of FTUI are presented in Table 1. As one of the largest faculties, FTUI is challenged to become one of the best engineering faculties in Indonesia; additionally, it aims for high quality in campus environmental conditions. The increasing demands for

\footnotetext{
Corresponding author: gakristanto@gmail.com
} 
water and energy, the generation of a large amount of solid wastes, and the low quality of wastewater are some of the issues that must be resolved.

Table 1. Faculty of engineering, University of Indonesia (FTUI) key statistics in 2014.

\begin{tabular}{|c|c|c|}
\hline Description & Number & Unit \\
\hline Total area & 10 & Hectares \\
\hline No. of departments & 7 & \\
\hline No. of students & 5,300 & People \\
\hline No. of academic lecturers & 350 & People \\
\hline No. of admin. personnel & 125 & People \\
\hline
\end{tabular}

To improve the quality of the environment, it is important to design a program that reflects consideration for the specific needs of the individual area. Each university environment is unique in terms of water and wastewater quality and quantity, solid waste composition, and energy consumption; therefore, defining a suitable program is important, especially when funding is limited. The availability of superior human resources, a reliable baseline environmental condition, and a strong commitment from campus management are some of the key factors that need to be considered when such a program is initiated. Additionally, setting up priorities and appropriating them into several sub-programs will enable achievement of the main goals.

The two-year development of the sustainable society program at FTUI is summarized in Figure 1, followed by a detailed description of each related activity. In the first year, the program focused on developing the system and infrastructure to support the development of a sustainable society. In the second year, emphasis shifted to increasing awareness and encouraging stakeholder participation.

\subsection{Water supply}

To maintain the supply of clean water at FTUI, two activities were developed: employing an artificial recharge system and monitoring water quality and groundwater levels throughout the year. The artificial recharge of groundwater is achieved by capturing rainwater in a shallow well so that the water infiltrates the soil and moves downward to recharge aquifers. The benefits of artificial recharges are well-documented and include reducing seawater intrusion or land subsidence, storing water, improving the quality of water through soil-aquifer treatment or geo purification, using groundwater in a water conveyance system, making groundwater out of surface water (for drinking) [6, 7, 8], and helping to reduce flooding. During this program, along with the development of artificial recharge wells, five piezometers were installed to monitor the level of groundwater.

The location of the three deep wells (SP01 to SP03), 27 artificial recharge wells, and piezometers wells (DB01 to DB05) on the FTUI campus are shown in Figure 2.

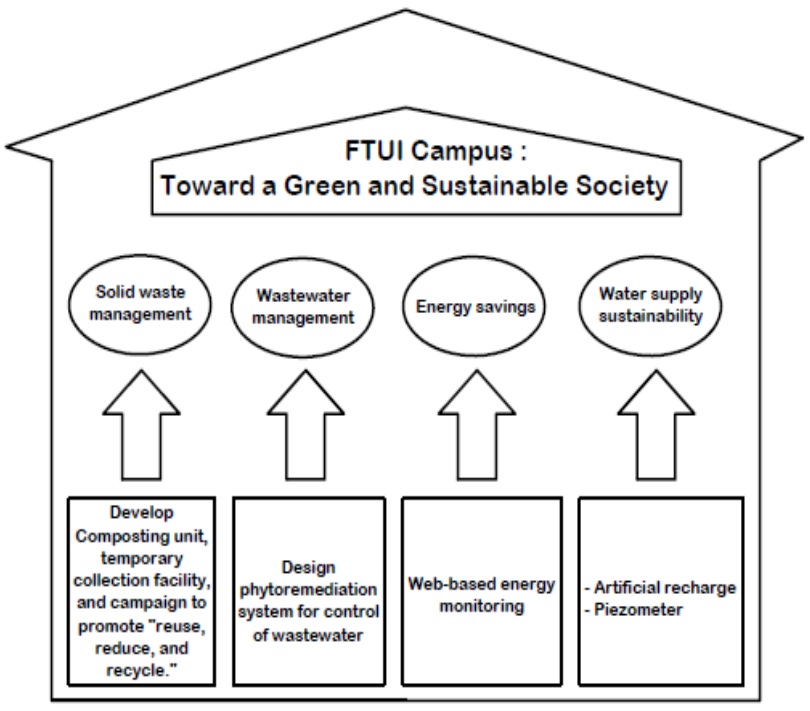

Fig. 1. Framework of FTUI green campus.

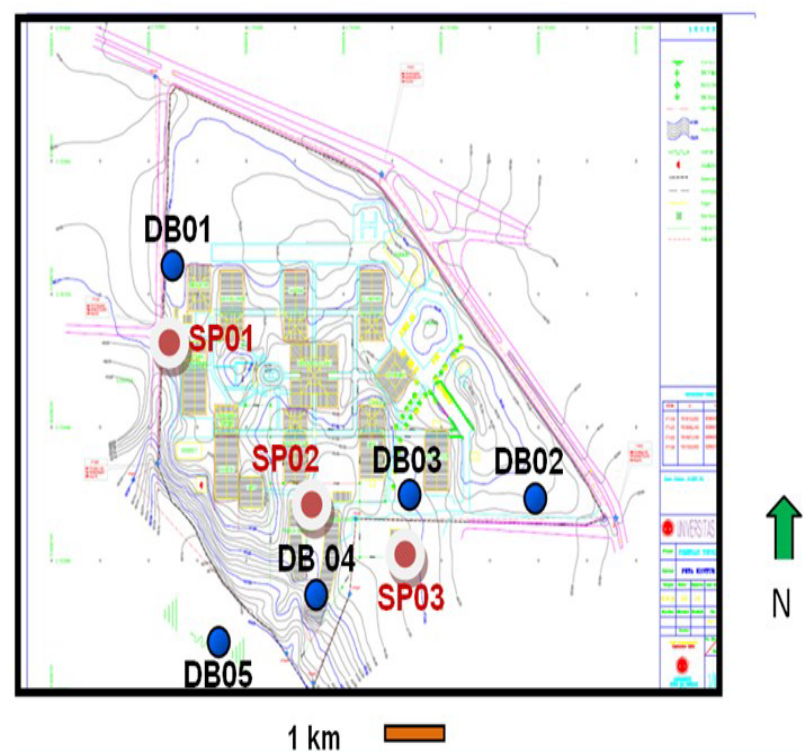

Fig. 2. Location of deep wells (red dots) and piezometric wells (blue dots) around the Engineering Faculty, University of Indonesia (FTUI) campus.

Twenty-seven of the shallow artificial recharge wells were designed by directing the rainwater into $0.8 \times 0.8 \times 1.1 \mathrm{~m} 3$ wells located in drainage intersections; hence, water penetrated directly into the aquifer. The groundwater quality was monitored by periodically sampling it from three deep wells near the artificial recharge wells. Monitoring groundwater level and water quality to maintain the water supply throughout the year, monitoring of groundwater levels and water quality was initiated through this program. Table 2 shows the laboratory test results for groundwater quality from each sampling point. 
Table 2. Water quality monitored at FTUI.

\begin{tabular}{|l|c|c|c|c|c|}
\hline Parameters & $\begin{array}{l}\text { Quality } \\
\text { standard }\end{array}$ & $\begin{array}{l}\text { Quality } \\
\text { standard }\end{array}$ & SP01 & SP02 & SP03 \\
\hline Color, Pt-Co & 15 & - & 127 & 4 & 4 \\
\hline $\begin{array}{l}\text { Chloride (Cl), } \\
\text { mg/L }\end{array}$ & 250 & - & 5.3 & 7.7 & 11.7 \\
\hline Turbidity, NTU & 5 & - & 39.2 & 0.36 & 1.12 \\
\hline $\mathrm{TDS}^{* * *}, \mathrm{mg} / \mathrm{L}$ & 500 & 1,000 & 88.3 & 147 & 258 \\
\hline pH & $6.5-8.5$ & $6-9$ & 5.32 & 5.8 & 6.4 \\
\hline Iron (Fe), mg/L & 0.3 & 0.3 & 1.11 & 0.04 & 0.23 \\
\hline $\begin{array}{l}\text { Manganese } \\
\text { (Mn), mg/L }\end{array}$ & 0.4 & 0.1 & 0.3 & 0.1 & 0.1 \\
$\begin{array}{l}*[9] \\
\text { **[10] } \\
* * * \text { Potentiometry method }\end{array}$ & & & & \\
\hline
\end{tabular}

Most of the tested water parameters were within safe limits (i.e., below the maximum level/threshold quality standards issued by both the Indonesian Health Ministry [9] and the Indonesian Government [10]. The results may have been potentially affected by the proximity of sampling locations to the artificial recharge wells established around the main Faculty building. In addition, the results may have been influenced by the dilution effect of excessive rainfall during the sampling period (May-June). On the other hand, the $\mathrm{pH}$ showed that the groundwater had a relatively high acidity, especially at SP01 (i.e., about 5.3). This result is in line with the previous results, probably because of the amount of $\mathrm{CO}_{2}$ in the soil that significantly affects acidity of the groundwater $[11,12]$. Contact between $\mathrm{CO}_{2}$ and water will form $\mathrm{H}_{2} \mathrm{CO}^{3}$, which causes the groundwater to become acidic. Meanwhile, the results of laboratory tests on water samples at SP02 and SP03 showed a similar quality issue in turbidity and Fe. In both samples, turbidity and Fe content showed fairly low values; however, the influence of drilling a new deep well (SP01) may have caused the fine materials and clay fragments to remain suspended in the water samples. In Figure 3, it shown the existing condition of groundwater levels recorded at each piezometric well from May 2013 to February 2014.

\subsection{Energy savings}

Energy is fundamental to human life. As the engine of the economy, it has become an integral part of society. For example, it is used to power cities, provide fuel for various types of vehicles, and set home and indoor temperatures. In other words, everything people do is connected to energy in one way or another. Since the Industrial Revolution, fossil fuels have been the main source for supporting the energy needs of mankind. Unfortunately, fossil fuels are non-renewable and emit different kinds of pollutants to the atmosphere. Therefore, there is a dire need to find options to improve energy efficiency in multiple sectors, including reducing the energy demands of buildings.

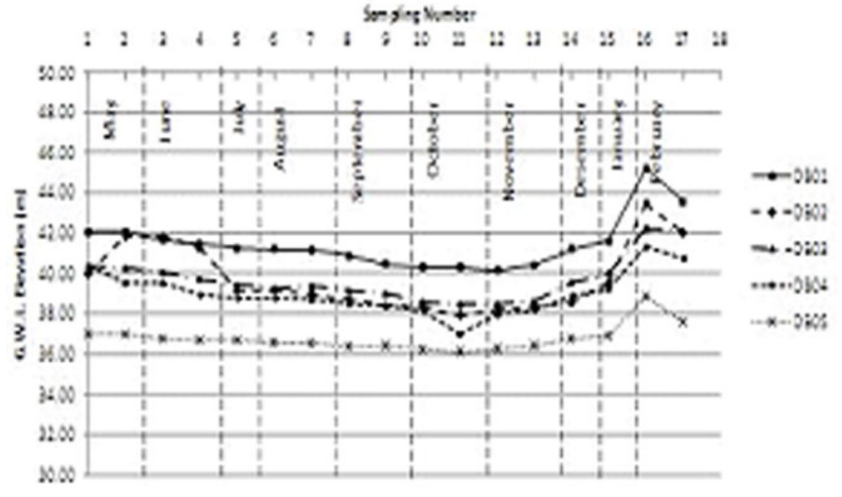

Fig. 3. Fluctuation of groundwater level at each piezometric well

During this program, several sustainable building concepts were analyzed. The main challenge for effective application of the concept on the FTUI campus was the fact that existing buildings are relatively old, having been built more than 15 years ago with limited implementation of energy-efficient designs. During the first year of this program, the energy-saving policy at FTUI was carried out in stages. The first stage included developing a policy cycle, meaning that all policies needed to continuously adhere toward achieving the overarching objectives. Policies included the UI's Rector Policy on Climate Change Mitigation at the University Campus, UI's Rector Policy on Energy Saving, and the Ministry of Energy's Decree on Electricity Saving. The second stage was to establish energy efficiency indicators. Baseline indicators, such as energy intensity for every room (including classrooms and administrative offices) and energy intensity for every student were applied and used to evaluate energy savings at year's end. To set up data for the baseline indicator, real-time electricity consumption was measured in one of the classrooms as a prototype of the smart energy building at FTUI. Data was gathered and converted to IP data and sent to the Green Campus server by LAN or WLAN. Using the proxy server in the Electrical Engineering Department (FTUI), data were made accessible via smartphones, tablets, or computers. Data were beneficial for analyzing electricity usage in real time and tracking energy and cost movements with each and every flip of the switch [7]. Such information can help faculty stakeholders understand which activities consume the most energy so that their consumption patterns, behaviors, and composition of appliances can be amended to reduce their electricity bills and carbon footprints.

\subsection{Wastewater treatment}

Currently, centralized wastewater treatment in Indonesia is very limited. Only $1 \%$ of domestic wastewater generated by the urban population is collected by municipalities and conveyed to a wastewater treatment plant. Most domestic wastewater is treated on-site (in home environments) using septic tanks (64\%). Thus, wastewater treatment is often regarded as a personal responsibility, as is the case for academic institutions. 
Although most of the black water at FTUI is treated using septic tanks, gray water is usually untreated and conveyed to the nearest body of water through the drainage system. This issue needs to be addressed based on the increasing quantities of wastewater and pollutants. During this project, it was identified that around $17 \%$ of the wastewater produced by FTUI originated from the faculty canteen. Although the amount is relatively small compared to other sources, its impact becomes more significant when wastewater quality is taken into account (Table 3). All parameters revealed that the effluent limit was exceeded by $2-10$ times. The concern is not only exceeding the limit of waste but also its discharge, which pollutes the artificial recharge lakes around the UI campus.

The ability to treat wastewater high in organics has been studied extensively during the last decades $[15,16$, $17,18]$. Several engineering designs were analyzed to determine a viable technology to treat canteen wastewater with a design flow rate of $1 \mathrm{~L} / \mathrm{s}[19,20]$. The combination of biological and phytoremediation is considered to be the most economical method; it requires low maintenance and zero energy. The plants patch in the phytoremediation process serves as a demonstration of landscape-friendly wastewater treatment. Prior to implementing the biological and phytoremediation processes, individual grease traps were installed in each sink. Afterwards, water passed through a bar screen for transport downstream to a $6 \mathrm{~m} 3$ anaerobic tank using an attached growth biological system. This treatment was followed by phytoremediation using Vetiveria zizaniodes-known as vetiver-with tall, tufted, perennial, scented grasses; long narrow leaves; and an abundant network of roots. It grows easily in the FTUI landscape.

\subsection{Solid waste management}

Developing solid waste management (SWM) programs is a key to achieving institutional sustainability [21, 22]. Effective SWM requires a complete understanding of the composition of waste streams as well as the activities that determine their generation in the first place [23, 24]. During the first year of this program, FTUI solid waste generation was characterized; further, a recycling system and compost houses were designed [25].

Characterization of FTUI waste was the first essential step toward greening the campus. This analysis helped decision makers at FTUI identify relevant opportunities in reducing and recycling wastes. The nature of the wastes indicated that among the recovery options, composting would be most appropriate as it would reduce more than $30 \%$ of the waste volume from the waste stream when providing compost for the faculty garden. The program was designed to use garden and food wastes as compost feedstock. During the first year, garden wastes were composted by the open windrow system; during the second year, a combination of food and garden wastes were treated in the in-vessel composting system.
Table 3. Effluent of the Engineering Faculty Canteen.

\begin{tabular}{|c|c|c|c|c|c|}
\hline \multirow{2}{*}{ Parameters } & \multirow{2}{*}{ Unit } & \multicolumn{2}{|c|}{$\begin{array}{c}\text { Canteen } \\
\text { wastewater } \\
\text { quality }\end{array}$} & \multicolumn{2}{|c|}{$\begin{array}{c}\text { Wastewater } \\
\text { regulation }\end{array}$} \\
\cline { 3 - 6 } & & $\mathbf{2 0 1 3}$ & $\mathbf{2 0 1 2}$ & $\begin{array}{c}\text { Quality } \\
\text { standar } \\
\mathbf{d}^{*}\end{array}$ & $\begin{array}{c}\text { Quality } \\
\text { standar } \\
\mathbf{d}^{* *}\end{array}$ \\
\hline $\mathrm{pH}$ & & 4.2 & 4.5 & $6-9$ & $6-9$ \\
\hline $\mathrm{TSS}$ & $\mathrm{mg} / \mathrm{L}$ & 286 & 498 & 100 & 50 \\
\hline Phosphorus & $\mathrm{mg} / \mathrm{L}$ & 194 & - & - & - \\
\hline COD & $\mathrm{mg} / \mathrm{L}$ & 2016 & 488 & - & 80 \\
\hline BOD & $\mathrm{mg} / \mathrm{L}$ & 159 & 185 & 100 & 50 \\
\hline $\begin{array}{c}\text { Oil and } \\
\text { grease }\end{array}$ & $\mathrm{mg} / \mathrm{L}$ & - & 115 & 10 & 20 \\
\hline
\end{tabular}

$* *[14]$

\section{Lessons learned}

Based on literature reviews and findings for developing a green environment, several key lessons are highlighted as follows; Lesson No. 1, Focus on designing a program, development of a green environment can be accomplished through several initiatives, such as providing the following: facilities and clean water systems, wastewater treatment, waste management, and clean energy. Each initiative has considerable options in technology and program selection; therefore, one should assess the potential applications of technology and programs based on characteristics of each initiative. Selection criteria should be prioritized with care. Technology applications-from the simple to the advanced-have pros and cons; thus, a "cost-benefit analysis based on need" must be performed and assessed thoroughly. The availability of reliable suppliers and resources for the various technologies is essential for supporting the continuity of the initiatives.

Lesson No. 2, Ensure continuous education and monitoring, involving faculty stakeholders in a community-based program is a key to the success of building a sustainable society [26]. Students, lecturers, administrative staffs, and cleaning service workers participated in this program in planning, collecting and analyzing data, designing, and reporting results. Their active participation was immediately beneficial for stakeholders in terms of establishing practices for growing and maintaining a green and sustainable society at the university. Several strategies were developed to increase stakeholder participation in this program. Increasing awareness and participation of stakeholders by providing sufficient information and education was prioritized to stimulate the adoption of a green campus program.

Incentives and rebates were created for participants to recycle according to each group's interests. However, monetary rewards could only be utilized to initiate new recyclers until they were able to sustain the habit of recycling [27]. In the future, the performance levels of recycling programs and participation need to be assessed $[28,29]$. Assessments will be beneficial for addressing 
certain factors that influence the recycling program and achieving more sustainable approaches to SWM.

Lesson No. 3, identify sources of funding, most of the funding available for universities in Indonesia is research-oriented, whereas funding for community awareness is limited in amount and availability. It is important to encourage each institution to establish a vision and mission on green infrastructures and allocate funding for the development of a green environment. The infrastructure serves as a start-up, but the operation, maintenance, and further development of a green environment must be consolidated to involve both the stakeholders and program team. For example, the polluter pays, meaning that the cost of pollution is borne by those who cause it. Essentially, the cost is the integration of water, wastewater, energy, and solid waste treatment. Some of the inherent expenses are offset by research grants and meal prices in the canteen. Ultimately, this system could be self-funded, especially as awareness among all stakeholders increases.

Implications of the findings for actual practice. The findings of this study demonstrate that defined programs, continuing education and monitoring, and sources of funding were critical factors in developing a green environment at FTUI. Two main limitations of this study were identified. First, it was based on conditions at UI; although some of the conditions related to other universities, care should be taken in making decisions regarding waste treatment and energy consumption in contexts outside UI. Second, regarding the lesson learned from actual practices in developing a green environment, improvements will not be realized without addressing other organizational issues such as culture, time, and sense of value. It is very important to undertake a comprehensive assessment before making decisions and understand the reasoning behind the methods and approaches used.

\section{Conclusion and recommendations}

To enhance the role of the university as an agent of change in Indonesia, FTUI aimed to be a pioneer in managing its campus environment by focusing on water, wastewater, SWM, and energy savings. Implementing the program resulted in building rainwater harvesting and artificial recharge systems, installing canteen wastewater treatment units, providing for SWM, designing energy-smart buildings, and involving stakeholders in every related activity. Support from all academic members and stakeholders through the effective dissemination of information and continuous education were keys for developing a successful and green environment at FTUI.

The authors would like to express deep gratitude to the Indonesia Ministry of Higher Education for supporting this research with funding under BOPTN 2013 Contract Number 1613/h2.PPK/PPM.00.01/2013.

\section{References}

1. K. Zaman, A.B. Abdullah, A. Khan, M.R.D. Nasir, T.A.A.T. Hamzah, S. Hussain, Dynamic Linkages among Energy Consumption, Environment, Health and Wealth in BRICS Countries: Green Growth Key to Sustainable Development, Renewable and Sustainable Energy Reviews, 56, 1263-1271 (2016)

2. World Commission on Environment and Development: Our Common Future. Available at: http://www.un-documents.net/our-commonfuture.pdf, accessed July $5^{\text {th }}$ (2015)

3. D.N. Norfadillah Derahin, H.S. Hashim, N. Ali, S.A. Abdul, G. Aziz, UKM's Staff Perspective on Sustainability and Its Contribution Towards a Sustainable University, Procedia-Social and Behavioral Sciences, 59, 376-381 (2012)

4. Y. Wang, H. Shi, M. Sun, D. Huisingh, L. Hansson, R. Wang, Moving Towards an Ecologically Sound Society? Starting from Green Universities and Environmental Higher Education. Journal of Cleaner Production, 61, 1-5 (2014)

5. N. Suwartha, R.F. Sari, Evaluating UI Greenmetric as a Tool to Support Green Universities Development: Assessment of the Year 2011 Ranking. Journal of Cleaner Production, 61, 46-53 (2013)

6. S. Patel, Water Management Conservation, Harvesting, and Artificial Recharge, New Age International, New Delhi (2008)

7. R.B. Thomas, M.J. Kirisits, D.J. Iye, K.A. Kinney, Rainwater Harvesting in the United States: A Survey of Common System Practices. Journal of Cleaner Production, 75, 166-173 (2014)

8. S.-H. Moon, J.-Y. Lee, B.-J. Lee, K.-H. Park, Y.-J. Jo, Quality of Harvested Rainwater in Artificial Recharge Site on Jeju Volcanic Island, Korea. Journal of Hydrology, 414-415, 268-277 (2012)

9. Decree of the Indonesia State Ministry of Health Ministry No. 492/MENKES/Per/IV/2010 on drinking water quality. Available at: http://www.litbang.depkes.go.id/sites/download/reg ulasi/permenkes/Permenkes_492-th-2010.pdf, accessed February $20 \mathrm{t}^{\mathrm{h}}(201 \overline{4})$

10. Government of Indonesian Law No. 82/2001 concerning management of water quality and control over water pollution. Available at: http://www.minerba.esdm.go.id/library/sijh/PP8201 KualitasAir.pdf, accessed February 20t ${ }^{\mathrm{h}}$ (2014)

11. $\bar{M}$. Gusnisar, The effect of recharge wells on the quality of groundwater in the Faculty of Engineering. Final project for bachelor's degree, Environmental Engineering Department, Faculty of Engineering, University of Indonesia, Jakarta (not published)

12. P. Freeze, J. Cherry, Groundwater, Prentice Hall, New Jersey (1979)

13. Decree of the Indonesia State Ministry of the Environment No. 112/2003 on effluent quality standards. Available at: http://www.iec.co.id/pdf/Kepmen\%20LH\%20No.\% 
2011203\%20\%28Baku\%20Mutu\%20Air\%20Limba

14. Jakarta Governor Regulation No. 112/2005 on domestic wastewater management. Available at: http://bplhd.jakarta.go.id/peraturan/pergub/pergub_1 22_2005.pdf, accessed June $3 \mathrm{t}^{\mathrm{h}}$ (2014)

15. S.S. Andra, R. Datta, D. Sarkar, S.K.M. Saminathan, C.P. Mullens, S.B.H. Bach, Analysis of Phytochelatin Complexes in the Lead Tolerant Vetiver Grass [Vetiveria zizanioides (L.)] Using Liquid Chromatography and Mass Spectrometry. Environmental Pollution, 157(7), 2173-2183 (2009)

16. Y. Chen, Z. Shen, X. Li, of Soils Contaminated with Heavy Metals. Applied Geochemistry, 19(10), 15531565 (2004)

17. M. Hammer, Water and Wastewater Technology, John Wiley and Sons, Singapore (1986)

18. J. Vymazal, Horizontal Sub-surface Flow and Hybrid Constructed Wetlands Systems for Wastewater Treatment. Ecological Engineering, 25(5), 478-490 (2005)

19. G. Moshiri, Constructed Wetlands for Water Quality Improvement. Lewis Publishers, London (1993)

20. Z. Li, H. Xiao, S. Cheng, L. Zhang, X. Xie, Z. Wu, A Comparison on the Phytoremediation Ability of Triazophos by Different Macrophytes. Journal of Environmental Sciences, 26(2), 315-322 (2014)

21. Y. Geng, K. Liu, B. Xue, T. Fujita, Creating a "Green University" in China: A Case of Shenyang University. Journal of Cleaner Production, 61, 1319 (2013)

22. K. Foo, A Vision on the Role of Environmental Higher Education Contributing to the Sustainable Development in Malaysia. Journal of Cleaner Production, 61, 6-12 (2013)
h\%20Domestik\%29.pdf, accessed June $3 \mathrm{t}^{\mathrm{h}}$ (2014)

23. C.A. de Vega, S.O. Benitez, E.R. Bareto, Solid Waste Characterization and Recycling Potential for a University Campus. Waste Management, 28(Supplement 1), S21-S26 (2008)

24. G. Tschobanoglous, H. Thiessen, S. Vigil, Integrated Solid Waste Management: Engineering Principles and Management Issues, McGraw-Hill Inc., Singapore (1993)

25. G.A. Kristanto, C.K. Banaget, I.G. Sofyan, A Baseline Study of Solid Waste Characterization and Recycling Potential at University of Indonesia, Proceedings of the Conference for Civil Engineering Research Networks, 62-67 (2014)

26. J.A. Fadamiro, A. Bobadoye, Managing the Building Design Process for Sustainabilty and Improved Quality. Civil Engineering Dimension, 8(1), 1-7 (2006)

27. Y.C. Moh, L.A. Manaf, Overview of Household Solid Waste Recycling Policy Status and Resources, Conservation and Recycling, 82, 50-61 (2014)

28. S. Suttibak, V. Nitivattananon, Assessment of Factors Influencing the Performance of Solid Waste Recycling Programs, Resource, Conservation, and Recycling, 53, 45-56 (2008)

29. A. Disterheft, S.F. Caeiro, R.M. Ramos, U.M. Azeiteiro, Environmental Management Systems (EMS) Implementation Processes and Practices in European Higher Education Institutions - Top-down Versus Participatory Approaches, Journal of The Use of Vetiver Grass (Vetiveria zizanioides) in the Phytoremediation Cleaner Production, 31, 8090(2012) 